\title{
VÝZNAM STRATEGICKÉHO MARKETINGOVÉHO ŘÍZENÍ V PODNICÍCH PRO ZVYŠOVÁNÍ JEJICH KONKURENCESCHOPNOSTI
}

\section{THE IMPORTANCE OF STRATEGIC MARKETING MANAGEMENT IN COMPANIES FOR INCREASE IN THEIRS COMPETITIVENES}

\author{
ING. ZDENĚK BEDNARČÍK, PHD. MBA \\ Katedra marketingu Department of Marketing \\ Obchodně podnikatelská fakulta v Karviné $\quad$ School of Business Administration in Karvina \\ Slezská univerzita v Opavě Silesian University in Opava \\ $\bowtie$ Univerzitni nám. 1934/3, 73340 Karviná, Czech Republic \\ E-mail: bednarcik@opf.slu.cz
}

\begin{abstract}
Anotace
$V$ článku jsou uvedeny dílči výstupy ze sekundárniho a primárniho výzkumu, prováděného v rámci projektu katedry marketingu SU OPF, zaměreného na malé a středni podnikání. Výzkum byl zaměren na posouzeni tvorby a významu marketingových strategii v podnikovém rízeni ve vybraných malých a střednich podnicích pro získáni konkurenční výhody na relevantnich trzích Ukazuje se, že nestači jen vytvorit odpovidajici strategii, ale podstatná je jeji implementace do praktické firemni cinnosti a predevšim jeji průběžná aktualizace.
\end{abstract}

\section{Kličcová slova}

konkurenční výhody, strategický marketing, plánování, strategické ř́zení, marketingové plánování, situační analýza, marketingová strategie, tržni pozice, marketingový výzkum

\section{Anotation}

In this article are introduce the results of secondary and primary research, performed in project of marketing department SU OPF. The research is aimed for small and middle enterprise. The research consider creation and importance of marketing strategies in small and middle companies for gaining of competitive advantage. There is analysis of using of marketing strategy for gain an advantages of competition. The current information-oriented times are more and more governed by competitive battles while the ability to hold onto a market position based merely on a material offer is not certain.

\section{Key words}

advantages of competition, strategic marketing, planning, strategic management, marketing planning, situation analysis, marketing strategy, target position, research of marketing

JEL classification: E52

\section{Úvod}

Pro trvalý rozvoj podniků a získávání tržních př́iležitostí je pro současný management nezbytné uplatňovat v řízení a podnikání marketingové zásady a principy, vytvářet a aktualizovat firemní strategii ve střednědobém i dlouhodobém horizontu, používat strategický marketing jako nástroj podnikového managementu.

Tento článek vychází z vlastního výzkumu v rámci Projektu katedry marketingu OPF v Karviné s názvem Cíleným výzkumem v oblasti malého a středního podnikání $\mathrm{k}$ dosažení konkurenceschopné znalostní ekonomiky. Dílčí sekundární a primární výzkum byl zaměřen na stav a úroveň strategického 
marketingového řízení v malých a stř̌edních podnicích, ověřil způsob tvorby marketingových strategií a jejich využití pro zvyšování konkurenceschopnosti podniků v období globalizace.

Posuzovány jsou zde způsoby a možnosti získávání konkurenční výhody zdokonalováním strategického marketingového rrízení, vytváření strategie odlišení od konkurence na základě využívání strategického marketingu jako nástroje firemního řízení v podnikové sféře .

\section{Pojetí konkurenční výhody}

Podle M. Portera existují pro podniky dva přístupy, jak předstihnout konkurenty. Porter tyto př́stupy popsal v knize Konkurenční strategie jako dvě základní generické strategie: Prvenství v celkových nákladech nebo Diferenciace (odlišení).

Podle mého názoru je hlavním úkolem manažerů zajistit dosahování cílů firmy (dosahování požadovaných tržeb, tržního podílu, zisku, apod.) a $\mathrm{k}$ naplnění těchto cílů může vést diferenciace oproti konkurenci.

Určitě dnes v tvrdém konkurenčním prostředí více než jindy platí: „Pro výrobce je dnes tedy hlavním problémem jak zaujmout zákaznika, aby se rozhodl právě pro jejich produkt, službu. " Manažeři, především marketéři, musí hledat způsoby, jak zaujmout zákazníka, jak ovlivňovat jeho nákupní rozhodování - tedy jak v očích zákazníků vytvořit odlišení, jedinečnou hodnotu. Tato jedinečná hodnota na základě diferenciace je v dnešní době tou nejvýznamnější konkurenční výhodou.

V dílčí výzkumné zprávě se při hledání konkurenční výhody zmiňuji rovněž o teorii diferenciace z hlediska uplatňování jednotlivých nástrojů marketingového mixu. Zabýval jsem se tedy i tvorbou hodnoty pro zákazníka, jak dosahovat vyššího uspokojení zákaznických potřeb a následně i vyšších zisků podniku. Nabídkou jedinečné hodnoty si podnik vlastně vytváří pozici dočasného monopolu (dokud odlišení není zkopírováno). (Foret, Stávková, 2003)

Cílem podniků je uspět na trhu, dosahovat dlouhodobě udržitelných výkonů - tržeb, postavení na trhu, ziskủ, apod. Úspěch na trhu je vždy v rámci konkurenčního boje - podnik, který chce uspět, musí mít výhodu před konkurencí - konkurenční výhodu.

Konkurenční výhoda, dle Slovníku marketingu, je určující charakteristika nebo stav, který podniku umožňuje odlišit se od konkurentů a překonat je. Konkurenční výhodou podniku může být schopnost poskytnout nejvyšší nebo jedinečný výkon nebo nabídnout nižší ceny oproti konkurenci.

Myslím si, že v obchodě platí stejně jako v umění výrok Paula Cézanna: ,, V umění je nejdůležitějši být jiný, nikoliv nejlepšì. “

V dnešní době se zákazníkům otevírají nové možnosti, které přinášejí zvýšené nároky a větší tlaky na podnikový management. Je zde na místě uvést mimo jiné (Kotler, Keller, 2004):

- Podstatné zyýšení kupní síly - snadné porovnání cen konkurentů (na internetu), možnost sdružování k dosažení většího objemu nákupu za výraznější slevy;

- Větší rozmanitost dostupného zboží a služeb - cokoliv lze objednat přes internet a z kteréhokoliv místa na světě; kupující se zemí s vysokými cenami mohou snížit výdaje objednávkami se zemí s nižšími cenami;

- Větší množství informací prakticky o čemkoliv - internet umožňuje př́stup k encyklopediím, slovníkům, spotřebitelským zprávám atd.;

- Snadnější vzájemné kontakty a podávání i přijímání objednávek - kupující mohou objednat cokoliv z domu, kanceláře nebo telefonu 24 hodin denně;

- Možnosti porovnat zprávy o výrobcích a službách - kupující si mohou on-line vyměňovat informace a názory; 


\section{Podniková strategie jako nástroj strategického ř́zení}

V zostřujícím se konkurenčním prostředí je kvalitní podniková strategie je jedním ze základních nástrojů strategického ř́zení k zajištění úspěšného dlouhodobého rozvoje podniku.

Zkušenosti se zpracováním podnikové strategie potvrzují, že jak praxe, tak i teorie prošly za poslední dvě desítky let bouřlivým vývojem. Lze současně tvrdit, že v souvislosti s výraznými změnami v ekonomickém a politické oblasti a zvláště v souvislosti s globalizací ekonomiky se tento vývoj nezastaví, ale naopak urychlí (Souček, Marek, 1998).

Upevnit a posílit konkurenční pozici podniku $\mathrm{v}$ dlouhodobém horizontu znamená, že manažeři ve vedení podniku musí zvládnout základní znalosti a dovednosti, jak kvalitní strategii zpracovávat, a jak ji úspěšně implementovat do života podniku.

I když existuje řada teorií, jak podnikovou strategii zpracovávat, není možné vytvořit jediný universální model. Každá podniková strategie je unikátní a představuje způsob, jakým chtějí manažeři zajistit úspěšný rozvoj podniku.

Zpracování kvalitní strategie podniku je náročné. Tím však práce manažerů zdaleka nekončí. Rozhodující je implementace strategie, při které manažeři musí v podniku vytvořit takové podmínky, které umožní strategii realizovat.

Právě při implementaci strategie se potvrzuje, že řízení je uměním. Jedná se především o umění jednat s lidmi uvnitř podniku, které musí manažeři získat pro naplnění všech záměrů obsažených ve strategii. Bez toho by strategie podniku byla jen kusem popsaného papíru (Vlček, 2002).

Nutno rovněž posoudit vzájemné vazby mezi celkovou firemní strategií a strategií marketingovou.

\section{Rozlišení pojmů strategie a marketingová strategie}

Strategie - v obecné poloze určité schéma postupu, jak za daných podmínek dosáhnout vytyčených cílů;

Pojem strategie má svůj původ v řečtině a znamená - volně přeloženo- umění velitele nebo generála. Ve slovníku obchodníků a výrobců se vždy tento termín spojuje se schopností rozhodovat na základě vysoké odbornosti a profesionality.

V obecném slova smyslu se strategií rozumí určité schéma postupu, tedy jakýsi návod, jak za daných podmínek dosáhnout vytyčených cílů. Představuje soubor možných postupů a činností, které jsou přijímány s vědomím částečné neznalosti všech budoucích podmínek, okolností a souvislostí, kdy nejsou poznány všechny náležitosti a skutečnosti pro úspěšné provedení budoucího rozhodování (Bednarčík, 2008).

Konečným cílem strategie je dospět k náležité součinnosti veškerých aktivit všech složek podniku a vytvořit jednotný celek jeho dalších perspektiv;

Marketingová strategie - charakterizuje směr k dosažení perspektivních marketingových cílů v rámci konkrétního marketingového prostředí (Jakubíková, 2008).

V oblasti marketingu se marketingová strategie orientuje na dosažení konkrétních marketingových cílů v náležitém marketingovém prostředí. Strategie nastiňuje směr, který bude organizační jednota sledovat $\mathrm{v}$ určitém časovém období, a který vede $\mathrm{k}$ nejúčinnější alokaci zdrojů pro dosažení stanovených marketingových cílů. 


\section{Aktualizace strategie}

V souladu s principem permanentnosti je obsah strategie nutno průběžně aktualizovat. Při aktualizaci se management musí racionálně vypořádat $\mathrm{s}$ dvěma protikladnými úkoly. Na jedné straně je žádoucí, aby strategie platila po určitou dobu (strategické období). Na druhé straně musí reagovat i na neočekávané změny. Při obrovské turbulentnosti světa je to velmi obtížný úkol.

Základem aktualizace strategie firmy je neustálé sledování změn, probíhajících uvnitř firmy i v jejím okolí. Především se ověřuje, zda hypotézy, na nichž je strategie firmy založena, byly správné a zda se tudiž okoli vyviji tak, jak se předpokládalo (Kotler, 2001).

Podklady pro tyto úvahy musí dodat manažerský a marketingový informační systém. Jejich údaje si ovšem každý člen vrcholového managementu musí sám doplňovat systematickým studiem odborné literatury, sledováním politické a společenské situace, poznatky z jednání s obchodními partnery a dalšími informacemi.

$\mathrm{Na}$ základě průběžně získaných informací vrcholový management rozhoduje, zda firma bude pokračovat $\mathrm{v}$ realizaci dosavadní strategie, či zda jsou nutné její určité dílčí korekce. Může rozhodnout též o přechodu $\mathrm{k}$ jiné již připravené variantě strategie. V krajním př́ípadě může dojít $\mathrm{k}$ situaci, kdy je nutno vypracovat zcela novou variantu strategie. Tato situace by měla být zcela výjimečná a mělo by $\mathrm{k}$ ní docházet pouze $\mathrm{v}$ případech skutečně zcela neočekávaných událostí. Těch by mělo být velmi málo.

Přechod na jinou strategii je obvykle náročný a nákladný. Je-li však dodržena zásada kompatibility mezi jednotlivými variantami, pak by při tomto přechodu nemělo dojít $\mathrm{k}$ ohrožení ekonomické stability firmy (Wessling, 2003).

Kromě průběžného sledování probíhajících změn se osvědčilo každoroční komplexní posouzení celého obsahu strategie a provedení jeji aktualizace. Posuzuje se jak vývoj okolí, tak i výsledky dosahované firmou a plnění jednotlivých strategických operací. Závěry se promítají do změn strategických operací, př́ípadně. i do vize a strategických cílů.

Aktualizace strategie je nedílnou a zcela nezbytnou součástí strategického řízení. Bez aktualizace by se strategie velmi brzy odtrhla od reality a stala by se zbytečným a málo používaným nebo zcela neužitečným dokumentem.

\section{Důvody vzniku strategického ř́zení}

Vznik strategického řízení si vynutily rychlé, často radikální změny zejména $v$ externím prostredí. Dalším z významných důvodů, vyvolávající potřebu strategického řízení, byla rostouci velikost podnikư s jejich složitostí a různorodostí.

Je tedy zřejmé, že předvídání budoucnosti pro všechny subjekty, ale zejména pro podnikatelské subjekty, se stává stále složitějším procesem, což vyvolává potřebu rychleji reagovat na nepředvídané změny. Teorie organizace formuluje role jednotlivců a propojuje je $\mathrm{s}$ cíli podniku. Teorie firmy propojuje cílově orientované podniky do tržních vztahů v podnikatelském prostředí.

Strategické řízení tedy řeší jak chování podniku ve vnějším prostředí, tak jeho vnitřní fungování v procesu jeho rozhodování a řízení. Podle Portera je ziskáni konkurenčni výhody jádrem výkonnosti každého podniku. Považuje za ni zejména výhodu nízkých nákladů, odlišení produktu od konkurence, technologickou dokonalost výrobku i technologie.

Podle Portera atraktivnost trhu, potenciální růst na trhu a možnost získat konkurenční výhodu závisí na stávající konkurenční struktuře trhu a schopnosti organizace vyrovnat se s pěti konkurenčními 
silami, které určují intenzitu odvětvové konkurence a ziskový potenciál odvětví. Jako rámec je možno zahrnout vliv státu na všechny konkurenční síly.

Podnik by měl zaujmout v odvětví takového postavení a zvolit takový př́istup ke konkurenci, který by omezil vliv konkurenčních sil a umožnil mu př́padně využít konkurenční síly v odvětví ve svůj prospěch a zaujmout pevnou pozici na daném trhu.

21. století přináší zásadní změny ve vývoji trhu i v řízení firem. Postatou změn je přechod od ekonomiky hmotných statků $\mathrm{k}$ ekonomice informační, která přináší úplně novou budoucnost.

Problém je, že se těžce odhaduje, jaká vlastně bude. Výsledné efekty ve firmách jsou předmětem spekulací. Některé změny jsou však již zřetelné (outsourcing, partnering, aliance) a posouvají firmy od byrokratických modelů řízení směrem k sítovým strukturám.

Všechny změny se budou samozřejmě odrážet i v činnosti marketingových oddělení. Nastává období nejistoty pro marketingové praktiky i teoretiky (Kotler, 2001).

\section{Zásady pro stanovení koncepce marketingové strategie}

Zásady pro konkrétní vyjádření koncepce marketingové strategie podniku lze shrnout do následujících bodů (Lyková, 2000):

- Rozhodování o efektivním vynaložení prostředků (stanovení výše těchto prostředků a jejich promyšlená alokace) do vybudovaného účinného vztahu výrobek - trh ve shodě s vytyčenými cíli podniku;

- Vytvoření a udržení prokazatelných konkurenčních předností na vytipovaných trzích;

Vytváření optimální strategie není jednorázovou činností, nýbrž neustálým procesem hledání a nacházení, pokusů a omylů a učení se z chyb konkurence. Strategie může být úspěšná, avšak musí být neustále přizpůsobován na měnící se podmínky trhu (Horáková, 2001).

Pokud firma nepůsobí v jednom ze dvou extrémních hospodářských prostředí, tedy v podmínkách dokonalé konkurence (kde musí firma následovat strategii ostatních konkurentů) nebo čistého monopolu (kde firma disponuje neomezeným vlivem), musí se ohlížet na možnou reakci konkurentů. Při rozhodování o zásadních krocích firmy v konkurenčním prostředí je významným pomocníkem taktéž teorie her, jež je využívána např́íklad při rozhodování o vstupu na trh, či v otázkách změn cenové politiky.

V marketingovém rozhodování je marketingovou strategií postup užití marketingu k dosažení cíle firmy. Marketingovou taktikou je pak její rozpracování do soustavy marketingových nástrojů $\mathrm{v}$ podobě marketingového mixu.

\section{Závěr}

V závěru je nutno připomenout, že chápání strategie jako nástrojů $\mathrm{k}$ dosažení cílů není jediné možné. Chápání strategie jako prostředků $\mathrm{k}$ dosažení cílů předpokládá, že známe cíl, umíme jej definovat (vyjádřit, uchopit) a k němu přiřazujeme jemu odpovídající prostřredky. Je to vnímání do značné míry mechanické, i když - na druhé straně - praktické a pedagogicky vysvětlitelné. Nicméně, v polovině 90. let 20. století se začalo prosazovat poněkud jiné, více systémové pojetí strategie. Na rozdíl od mechanického řazení strategie - cíl se strategií začíná. Cíl se stává součástí strategie, respektive strategií se rozumí i vymezení cílů (strategické zacílení) (Jakubíková, 2008).

Výsledky provedených výzkumů ukazují v řadě př́ípadů na nepochopení některých zásadních principů strategického marketingového rrízení, na nesprávné pojetí nástrojů a metod strategického marketingu i na nerespektování vývojových změn v pojetí marketingového řízení podniků. V průběhu výzkumu se 
opakovaly názory vrcholových manažerů nebo majitelů jednotlivých podniků, že předchozí uvedené činnosti mají zajištovat pracovníci marketingového nebo obchodního útvaru a jen oni mají plnou zodpovědnost za péči o zákazníky, hledání nových zákazníků a tržních příležitostí.

\section{Literatura}

[1] BEDNARČÍK, Z. Strategický marketing. Karviná: Slezská univerzita v Opavě, 2008. ISBN 978-80-7248-436-2.

[2] FORET, M. a STÁVKOVÁ, J. Marketingový výzkum. Jak poznávat své zákazníky. Praha: Grada Publishing, 2003. 160 s. ISBN 80-247-0385-8.

[3] HORÁKOVÁ, H. Strategický marketing.Praha: Grada Publishing 2001. ISBN 80-7169- 996- 9.

[4] JAKUBÍKOVÁ, D. Strategický marketing. Praha: Grada Publishing, 2008, 272 s. ISBN 97880-247-2690-8.

[5] KOTLER P. Marketing management. Praha: Grada Praha, 2001. ISBN 80-247-00016-6.

[6] KOTLER, P., KELLER,K.L. Marketing Management. Praha: Grada Publishing, 2004. ISBN 80-247-0513-3.

[7] LYKOVÁ, J. Marketingový audit a kontrola. Praha: Grada Publishing, 2000. ISBN 80-7169$720-6$.

[8] SOUČEK,Z. , MAREK, J. Strategie úspěšného podniku. Ostrava: Montanex 1998. ISBN 8085780- 93- 3.

[9] VLČEK, R. Hodnota pro zákazníka. Praha: Management Press, 2002. ISBN 80-7261-068-6.

[10] WESSLING, H. Aktivni vztah k zákazníkům pomocí CRM - Strategie, praktické př́klady a scénáre. Praha: Grada publishing, 2003. ISBN 80-247-0569-9. 